\title{
PENGUKURAN KINERJA LEMBAGA PERKREDITAN DESA (LPD) KECAMATAN SUSUT DENGAN ANALISIS BALANCED SCORECARD
}

\author{
Gede Putu Agus Jana Susila \\ Universitas Pendidikan Ganesha Singaraja-Bali \\ e-mail: Janos_undiksha@yahoo.com
}

\begin{abstract}
Abstrak
Kehadiran LPD di desa memberi manfaat yang sangat besar untuk kehidupan ekonomi masyarakat desa. Manfaat yang diperoleh yaitu mampu memberikan kredit untuk warga desa dengan bunga yang relatif kecil, dalam proses pemberian kredit pada calon nasabah fleksibel atau tidak dipersulit, memeratakan perekonomian di desa adat, terciptanya lapangan kerja, dan adanya LPD dapat menjaga pembangunan desa adat. Dengan adanya LPD diharapkan angka kemiskinan pada daerah lingkup LPD menjadi menurun. Penelitian ini bertujuan untuk mengetahui kinerja LPD Kecamatan Susut yang dinilai dengan Metode Balanced Scorecard dan menilai dari masing-masing perspektif yaitu keuangan, pelanggan, proses bisnis internal, serta pertumbuhan dan pembelajaran. Sesuai dengan tujuan itu maka, desain penelitian ini merupakan penelitian deskriptif kuantitatif yang didalamnya memberikan penjelasan tentang kinerja LPD dengan metode Balanced Scorecard. Perspektif keuangan dalam Balanced Scorecard mengarahkan kinerja dalam menciptakan nilai dan memberikan perbaikan yang mendasar pada perusahaan melalui perhitungan permodalan, aktiva produktif, rentabilitas, dan likuiditas. Pada perspektif proses bisnis internal, mengukur proses pemberian kredit di LPD Kecamatan Susut digunakan Manufacturing Cycle Effectiveness (MCE) untuk menghindari waktu yang terbuang dalam proses pemberian kredit, sedangkan penilaian kinerja dari perspektif pelanggan yang menjabarkan kepuasan pelanggan, serta perspektif pertumbuhan dan pembelajaran yang menjabarkan kepuasan karyawan digunakan penyebaran kuesioner dengan menggunakan skala likert. Dengan menggunakan Balanced Scorecard, akan mengetahui bagaimana kinerja di LPD Kecamatan Susut tidak hanya dari perspektif keuangan melainkan juga dari tiga perspektif non-keuangan yang meliputi perspektif pelanggan, perspektif proses bisnis internal, serta perspektif pertumbuhan dan pembelajaran. Penilaian perspektif keuangan dan non-keuangan dapat mengintegrasikan seluruh aspek kinerja LPD Kecamatan Susut. Penilaian kinerja LPD secara keseluruhan yang dinilai dengan metode balanced scorecard berada pada kategori cukup baik, karena diperoleh skor sebesar 2089,13 dan skor ini berada pada interval 1359-2716. Kondisi ini mengimplikasikan bahwa kinerja LPD masih perlu ditingkatkan agar berada pada kategori sangat baik dengan meningkatkan kinerja LPD dari perspektif keuangan, perspektif pelanggan, serta perspektif pertumbuhan dan pembelajaran
\end{abstract}

Kata Kunci: Balanced Scorecard, Penilaian Kinerja, Lembaga Perkreditan Desa (LPD)

\begin{abstract}
LPD presence in the village gave a huge benefit to the economic life of the villagers. The benefits derived are able to provide loans to villagers with relatively little interest, in the process of granting credit to prospective customers flexible or not compounded, to distribute evenly in the traditional village economy, job creation, and the LPD can maintain traditional rural development. With the LPD expected scope of poverty in the region declined LPD. This study aims to determine the performance of the District LPD Losses were assessed with Balanced Scorecard method and judging from their respective perspectives: financial, customer, internal business processes, and learning and growth. In accordance with that purpose then, the design of this research is quantitative descriptive study in which provides an explanation of the performance of LPD with the Balanced Scorecard method. Financial perspective in Balanced Scorecard directing the performance in creating value and provide a fundamental improvement in the company through the calculation of capital, assets, profitability and liquidity. In the
\end{abstract}


internal business process perspective, measuring the credit granting process in LPD District of Susut used Manufacturing Cycle Effectiveness (MCE) to avoid time wasted in the process of granting a credit, while the performance assessment of the customer's perspective that lays customer satisfaction, as well as learning and growth perspective that lays satisfaction employee use of questionnaires using Likert scale. Using the Balanced Scorecard, will determine how the performance in the District LPD Losses not only from a financial perspective but also from the three non-financial perspectives that includes customer perspective, internal business processes, learning and growth perspective. Ratings financial perspective and non-financial performance can integrate all aspects of the District LPD shrinkage. LPD overall performance ratings assessed by the method of balanced scorecard in the category quite well, because obtained a score of 2089.13 and this score is in the interval 1359 - 2716. This condition implies that the performance LPD still needs to be improved to be in a very good category with LPD improve the performance of the financial perspective, customer perspective, and learning and growth perspective

Keywords: Balanced Scorecard, Performance Appraisal, Village Credit Institutions (LPD)

\section{LATAR BELAKANG}

LPD adalah Lembaga Perkreditan Desa di Desa Pakraman dalam Wilayah Propinsi Bali yang oleh Peraturan Daerah (Perda) diakui dan dikukuhkan dalam status hukum sebagai suatu bentuk badan usaha keuangan, dengan sifat yang bersifat khusus, karena hanya menyelenggarakan kegiatan usaha dalam wilayah desa, Nurjaya, dkk. (2001:35-36). Sebagai suatu lembaga perkreditan desa, LPD tentu memiliki tujuan yang sama dengan lembaga perbankan lainnya yaitu untuk mencari keuntungan yang nantinya bisa dikelola untuk kepentingan warga desa. Menurut Suartana (2009:3), ada beberapa faktor yang menyebabkan belum majunya LPD, yaitu (1) tidak siapnya Sumber Daya Manusia (SDM) dalam mengelola usaha ini, (2) tidak adanya komitmen pengampu kepentingan di desa pakraman untuk memajukan LPD, (3) warga desa tidak kompak mendukung keberadaannya, dan (4) belum dipahaminya secara benar bahwa LPD itu adalah suatu kesatuan usaha yang memiliki otonomi dan diskresi dalam mengelola usahanya. Dengan adanya LPD diharapkan angka kemiskinan pada daerah lingkup LPD menjadi menurun.

Dari permasalahan tersebut maka perspektif non-financial dianggap sebagai bagian yang perlu diperhatikan, sehingga dapat mendongkrak kinerja keuangan yang merupakan keinginan utama dari pemegang saham. Perusahaan harus mempunyai strategi yang dituangkan dalam tindakan-tindakan, agar dapat menjaga kelangsungan usaha Lembaga Perkreditan Desa (LPD). Penilaian kinerja juga harus lebih dari sekedar penilaian financial. Metode yang dapat mengintegrasikan seluruh aspek yang terkait dalam perusahaan yaitu metode Balanced Scorecard. Metode ini mengukur kinerja perusahaan berdasarkan empat perspektif yaitu keuangan, pelanggan, proses bisnis internal, serta pertumbuhan dan pembelajaran sehingga dapat diperoleh pencapaian tujuan perusahaan yang lebih efektif dan terintegrasi. Adapun tujuan penelitian ini adalah untuk mengetahui Kinerja LPD Kecamatan Susut ditinjau dari perspektif keuangan, perspektif pelanggan, perspektif proses bisnis internal, serta perspektif pertumbuhan dan pembelajaran. Menurut Suartana (2009:12), Lembaga Perkreditan Desa merupakan lembaga keuangan milik desa pakraman yang telah berkembang, memberikan manfaat sosial, ekonomi, dan budaya kepada anggotanya sehingga perlu dibina, ditingkatkan kinerjanya, diperkuat serta dilestarikan keberadaannya. Secara lebih luas menurut Nurjaya, dkk. (2011:35-36), Pasal 2 ayat (1) Peraturan daerah tersebut menyatakan bahwa: Lembaga Perkreditan Desa merupakan suatu badan usaha keuangan milik Desa yang melaksanakan kegiatan usaha di lingkungan Desa dan untuk warga Desa. Ketentuan tersebut menunjukkan bahwa Lembaga 
Perkreditan Desa merupakan suatu bentuk lembaga ekonomi, yang oleh perda diakui dan dikukuhkan dalam status hukum sebagai suatu bentuk badan usaha keuangan, dengan sifat khusus, karena hanya menyelenggarakan kegiatan usaha dalam wilayah desa. Menurut Nurjaya, dkk. (2011:95), Tujuan Lembaga Perkreditan Desa adalah sebagai berikut: 1) Mendorong pembangunan ekonomi masyrakat desa melalui tabungan yang terarah serta penyaluran modal yang efektif; 2) Menciptakan pemerataan dan kesempatan berusaha bagi warga desa dan tenaga kerja di pedesaan; 3) Meningkatkan daya beli dan melancarkan lalu lintas pembayaran dan peredaran uang di desa.

Berdasarkan Pasal 2 angka 1 Perda LPD No. 8/2002, menyatakan bahwa: "LPD merupakan badan usaha keuangan milik desa yang melaksanakan kegiatan usaha di lingkungan desa dan untuk krama desa". Ketentuan dalam Pasal 2 angka 1 Perda LPD No. 8/2002 menunjukkan bahwa LPD merupakan suatu bentuk lembaga ekonomi, yang oleh Perda diakui dan dikukuhkan dalam status hukum sebagai suatu bentuk badan usaha keuangan. Bentuk badan usaha keuangan LPD bersifat khusus karena hanya menyelenggarakan kegiatan usaha dalam wilayah desa pakraman. Pasal 7 ayat (1) Perda LPD No. 8/2002 berkaitan dengan lapangan usaha yang dijalankan oleh LPD. Lapangan usaha LPD mencakup: a) Menerima dan menghimpun dana dari krama desa dalam bentuk keuangan dan deposito; b) Memberikan pinjaman hanya kepada krama desa; c) Menerima pinjaman dari lembaga-lembaga keuangan maksimum sebesar $100 \%$ dari jumlah modal, termasuk cadangan dan laba ditahan, kecuali batasan lainnya dalam jumlah pinjaman atau dukungan/bantuan dana; d) Menyimpan kelebihan likuiditasnya pada BPD dengan imbalan bunga bersaing dan pelayanan yang memadai.

Berdasarkan substansi ketentuan Perda di atas, menunjukkan bahwa LPD merupakan suatu badan usaha keuangan khusus. Adapun ciri-ciri LPD sebagai lembaga keuangan khusus, yaitu sebagai berikut: a) Merupakan milik desa pakraman; b) Dibentuk dan dikelola oleh desa pakraman; c) Menyelenggarakan fungsi-fungsi kelembagaan keuangan komunitas desa pakraman, seperti menerima/menghimpun dana dari krama desa, memberikan pinjaman hanya kepada krama desa, dan mengelola keuangan lembaga tersebut, hanya pada lingkungan desa pakraman; dan d) Menyelenggarakan fungsi usaha sebagai lembaga usaha keuangan internal

desa pakraman, atau sejauh jauhnya antardesa pakraman. Salah satu usaha yang dijalankan oleh LPD seperti tersebut di atas adalah memberikan kredit kepada masyarakat. Pemberian kredit merupakan kegiatan utama dari LPD yang mengandung resiko paling tinggi dan dapat mempengaruhi kesehatan dan kelangsungan dari LPD selaku kreditor.

Menurut Nurjaya, dkk. (2011:95-96), usaha LPD adalah sebagai berikut; 1) Menerima simpanan uang dari warga masyarakat desanya dalam bentuk tabungan dan simpanan berjangka; 2) Memberikan pinjaman untuk kegiatankegiatan yang bersifat produktif pada sektor pertanian, dan kerajinan kecil; 3) Usaha-usha yang bersifat pengarahan dana desa; 4) Penyertaan modal pada usaha-usaha lainnya.; 5) Menerima pinjaman dari lembaga-lembaga keuangan. Keberhasilan pencapaian strategik yang menjadi basis pengukuran kinerja perlu ditentukan ukurannya dan ditentukan inisiatif strategik untuk mewujudkan sasaran tersebut. Sasaran strategik beserta ukurannya kemudian digunakan untuk menentukan target yang akan dijadikan basis penilaian kinerja (Mulyadi, 2007:337). Kinerja adalah gambaran mengenai tingkatan pencapaian pelaksanaan suatu kegiatan/ program. Kebijaksanaan dalam mewujudkan sasaran, tujuan, visi, dan misi organisasi yang tertuang dalam perumusan skema strategis (strategic planning) suatu organisasi (Indra Bastian, 2001).

Menurut Yuwono, dkk. (2002), pengukuran kinerja sebagai tindakan pengukuran yang dilakukan terhadap berbagai aktivitas dalam rantai nilai yang ada pada perusahaan. Hasil pengukuran 
tersebut kemudian digunakan sebagai umpan balik yang akan memberikan informasi tentang prestasi pelaksanaan suatu rencana dan titik dimana perusahaan memerlukan penyesuaianpenyesuaian atas aktivitas perencanaan dan pengendalian.

Balanced Scorecard mendidik manajemen, dan organisasi untuk memandang perusahaan dari empat perspektif yaitu (1) perspektif keuangan, (2) perspektif pelanggan, (3) perspektif proses bisnis internal, serta (4) perspektif pertumbuhan dan pembelajaran; yang menghubungkan pengendalian operasional jangka pendek kedalam visi, misi, dan strategi bisnis jangka panjang. Selanjutnya manajemen didorong untuk memfokuskan diri pada rasio-rasio kunci yang kritis dan strategis melalui stretch target yang ditetapkan bersama. Menurut Suartana (2009), Balanced Scorecard adalah sistem pengelolaan (bukan hanya sistem pengukuran) yang dapat membantu organisasi untuk menjelaskan visi, dan strategi mereka, serta menerapkan dalam operasinya.

Penilaian Balanced Scorecard menurut Suartana (2009), mencangkup empat perspektif yang meliputi hal-hal sebagai berikut: 1) Perspektif keuangan adalah perspektif ini mengukur kinerja dari sudut pandang penyedia sumber daya dan ketercapaian target keuangan sebagaimana yang ditetapkan pada anggaran Lembaga Perkreditan Desa; 2) Persepektif pelanggan adalah perspektif ini merupakan indikator bagaimana nasabah melihat Lembaga Perkreditan Desa dan bagaimana Lembaga Perkreditan Desa memandang mereka. Indikator utama yang dapat digunakan untuk menilai bagaimana nasabah memandang Lembaga Perkreditan Desa adalah tingkat kepuasan nasabah yang bisa diketahui melalui survei pelanggan, adanya pengaduan, sikap dan perilaku mereka yang dapat diketahui dari keluhan-keluhan yang mereka sampaikan, sehingga dengan demikian loyalist pelanggan dapat terjaga; 3) Perspektif proses bisnis internal adalah perspektif ini digunakan untuk mengevaluasi apakah proses telah mengalami peningkatan dan sejajar dengan patok duga atau mencapai standar yang ditetapkan; 4)Persepektif pertumbuhan dan pembelajaran adalah perspektif ini mencakup manfaat dari pengembangan baru dan bagaimana hal ini dapat memberikan kontribusi bagi kesuksesan di masa depan.

\section{Empat Kinerja Kunci LPD}

\begin{tabular}{|c|c|}
\hline No & Faktor strategis internal kunci \\
\hline 1 & $\begin{aligned} & \text { Kinerja perspektif keuangan } \\
&- \text { Return On Asset (ROA). } \\
& \text { - } \text { Biaya Operasional Pendapatan Operasional (BOPO). } \\
& \text { - } \text { Capital Adequancy Ratio (CAR). } \\
& \text { - } \text { Non Performing Loan (NPL). } \\
&- \text { Return On Equity (ROE). } \\
&- \text { Loan Deposit Ratio (LDR). }\end{aligned}$ \\
\hline 2 & $\begin{array}{l}\text { Kinerja perspektif nasabah } \\
\text { - } \quad \text { Jenis - jenis produk dan variannya } \\
\text { - } \quad \text { Level suku bunga } \\
\text { - } \quad \text { Biaya administrasi dan provisi } \\
\text { - } \quad \text { Kegiatan promosi }\end{array}$ \\
\hline 3 & $\begin{array}{l}\text { Kinerja perspektif proses bisnis internal } \\
\text { - Proses permohonan kredit (pengajuan permohonan kredit, pengisian } \\
\text { formulir dan perjanjian kredit, penyelidikan berkas pinjaman, rapat } \\
\text { keputusan pemberian kredit, dan penandatanganan perjanjian kredit). } \\
\text { - Lamanya pencairan kredit. }\end{array}$ \\
\hline 4 & $\begin{array}{c}\text { Kinerja perspektif pertumbuhan dan pembelajaran } \\
\text { - } \quad \text { Tingkat pendidikan } \\
\text { - } \text { Pengembangan karir }\end{array}$ \\
\hline
\end{tabular}




\begin{tabular}{|l|ll|}
\hline No & \multicolumn{1}{c|}{ Faktor strategis internal kunci } \\
\hline & - & Sistem remunerasi atau penggajian \\
& - & Fleksibilitas organisasi \\
& - & Tingkat ketersediaan informasi \\
& - & Tingkat kepuasan kerja \\
& - & Tingkat produktivitas karyawan LPD \\
\hline
\end{tabular}

\section{METODE PENELITIAN}

Penelitian ini bertujuan untuk mengetahui kinerja LPD Kecamatan Susut yang dinilai dengan Metode Balanced Scorecard dan menilai dari masingmasing perspektif yaitu keuangan, pelanggan, proses bisnis internal, serta pertumbuhan dan pembelajaran. Sesuai dengan tujuan itu maka, desain penelitian ini merupakan penelitian deskriptif kuantitatif yang didalamnya memberikan penjelasan tentang kinerja LPD dengan metode Balanced Scorecard. Perspektif keuangan dalam Balanced Scorecard mengarahkan kinerja dalam menciptakan nilai dan memberikan perbaikan yang mendasar pada perusahaan melalui perhitungan permodalan, aktiva produktif, rentabilitas, dan likuiditas. Pada perspektif proses bisnis internal, mengukur proses pemberian kredit di LPD Kecamatan Susut digunakan Manufacturing Cycle Effectiveness (MCE) untuk menghindari waktu yang terbuang dalam proses pemberian kredit, sedangkan penilaian kinerja dari perspektif pelanggan yang menjabarkan kepuasan pelanggan, serta perspektif pertumbuhan dan pembelajaran yang menjabarkan kepuasan karyawan digunakan penyebaran kuesioner dengan menggunakan skala likert. Dengan menggunakan Balanced Scorecard, akan mengetahui bagaimana kinerja di LPD Kecamatan Susut tidak hanya dari perspektif keuangan melainkan juga dari tiga perspektif non-keuangan yang meliputi perspektif pelanggan, perspektif proses bisnis internal, serta perspektif pertumbuhan dan pembelajaran. Penilaian perspektif keuangan dan non-keuangan dapat mengintegrasikan seluruh aspek kinerja LPD Kecamatan Susut.

Variabel dalam penelitian ini yaitu (1) perspektif keuangan, (2) perspektif pelanggan yang dinilai dari kepuasan pelanggan. (3) perspektif proses bisnis internal yang menjabarkan proses pemberian kredit, (4) serta perspektif pertumbuhan dan pembelajaran yang menilai kinerja LPD dari kepuasan karyawan. Penelitian ini dilaksanakan di LPD Kecamatan Susut Kabupaten Bangli yang datanya diambil dari LPLPD Kabupaten Bangli, Propinsi Bali. Yang menjadi Subyek dalam penelitian ini adalah LPD, Pimpinan LPD, serta Pegawai dan Pelanggan LPD di Kecamatan Susut Kabupaten Bangli. Objek penelitian ini adalah kinerja LPD yang dilihat dari empat perspektif yaitu perspektif keuangan, perspektif pelanggan, perspektif proses bisnis internal, serta perspektif pertumbuhan dan pembelajaran yang digunakan untuk menilai kinerja LPD Kecamatan Susut.

Teknik pengumpulan data yang digunakan dalam penelitian ini adalah sebagai berikut.: 1) Kuesioner yaitu teknik pengumpulan data melalui daftar pertanyaan tertulis yang diberikan pada karyawan dan pelanggan untuk menilai LPD dari perspektif pelanggan, serta perspektif pertumbuhan dan pembelajaran; 2) Dokumentasi yaitu dokumentasi adalah pengumpulan data dengan membaca atau mencatat dokumen-dokumen resmi yang terarsip di LPD berupa Neraca, laba rugi, serta data jumlah pegawai dan pelanggan LPD Kecamatan Susut; 3) Wawancara yaitu teknik pengumpulan data dengan mengajukan pertanyaan langsung mengenai keadaan LPD dan proses pemberian kredit yang ada di Kecamatan Susut Kabupaten Bangli khususnya pada pimpinan LPD Sekecamtan Susut, karyawan dan pelanggan yang berkompeten yang berhubungan dengan penelitian untuk menunjang data.

\section{HASIL PENELITIAN}

Penilaian Kinerja LPD Kecamatan Susut Ditinjau dari Perspektif Keuangan, perspektif pelanggan, perspektif proses bisnis internal, serta perspektif pertumbuhan dan pembelajaran; 1) 
Kinerja LPD ditinjau dari perspektif keuangan yaitu penilaian kinerja LPD yang ditinjau dari perspektif keuangan diukur berdasarkan rasio-rasio keuangan yang meliputi (a) Capital Adequency Ratio (CAR), (b) rasio Return On Assets (ROA), (c) Biaya Operasional terhadap Pendapatan Operasional (BOPO), (d) rasio Return On Equity (ROE), (e) rasio Loan to Deposit Ratio (LDR), dan (f) rasio Non Performing Loan (NPL), secara keseluruhan dapat dikategorikan Cukup Sehat karena berdasarkan penggolongan tingkat kesehatan LPD berada pada angka 66 - <81. Walaupun dari segi keuangan belum memenuhi target namun kinerja keuangan LPD yang ditinjau dari segi keuangan dapat ditingkatkan lagi di tahun berikutnya dengan lebih memperhatikan lagi rasio-rasio yang digunakan untuk menilai kinerja LPD dari segi keuangannya seperti rasio NPL dan rasio LDR; 2) Kinerja LPD Ditinjau dari Perspektif Pelanggan yaitu penilaian kinerja perspektif pelanggan ini diukur dari indeks kepuasan pelanggan melalui kuisioner yang disebar kepada pelanggan. Hasil pengolahan data IKP yang terdiri dari empat dimensi yaitu: (1) jenis-jenis produk atau variannya, (2) level suku bunga, (3) biaya administrasi atau provisi, dan (4) kegiatan promosi, maka diperoleh Indeks Kepuasan Pelanggan sebesar 5.430, sehingga pelanggan dapat dikategorikan cukup puas atas produk yang diberikan oleh LPD. Hal ini berarti LPD sudah cukup mampu mencapai indeks kepuasan pelanggan karena sudah mampu membuat pelanggan secara keseluruhan merasa cukup puas atau berada dalam interval antara 4162 - 5442. Walaupun kurang memenuhi target, tetapi indeks ini masih dapat ditingkatkan lagi pada tahun yang akan datang seperti dalam hal level suku bunga, biaya administrasi atau provisi, dan kegiatan promosi; 3) Kinerja LPD Ditinjau dari Perspektif Proses Bisnis Internal yaitu penilaian kinerja perspektif proses bisnis internal ini diukur dari keefektifan waktu yang diperlukan dalam proses pemberian kredit. Pihak LPD menentukan beberapa syarat dan proses di dalam pemberian kredit kepada nasabah yang ingin mendapatkan kredit yang meliputi (1) pengajuan permohonan kredit, (2) pengisian formulir dan perjanjian kredit, (3) penyelidikan berkas pinjaman, (4) rapat keputusan pemberian kredit, (5) penandatanganan perjanjian kredit, dan (6) pencairan kredit. Dari persyaratan tersebut maka manajemen LPD menetapkan standar waktu proses pemberian kredit 102 menit. Selama 60 hari peneliti melakukan pengamatan yang menjadi anggota sampel dengan lima calon debitur dari masing-masing LPD, diperoleh rata-rata penyelesaian proses pemberian kredit yang sesungguhnya adalah 99,03 menit. Hasil perhitungan tersebut menunjukkan bahwa kinerja perspektif proses bisnis internal yang dicari dengan rumus MCE yaitu perbandingan antara waktu pengolahan dengan waktu penyelesaian pemberian kredit pada LPD adalah 1,03 menit. Hasil Manufacturing Cycle Effectiveness (MCE) menunjukkan > 1 maka, hal ini berarti kinerja LPD dalam melaksanakan proses pemberian kredit kepada nasabah berjalan efektif karena waktu yang diperlukan lebih cepat dari waktu yang telah ditetapkan. Hal ini disebabkan karena karyawan lebih tanggap dalam melayani pelanggannya serta lebih menghargai waktu karena berdasarkan keterangan beberapa karyawan yang ada di LPD, semakin cepat dapat menyelesaikan pekerjaannya maka semakin banyak mereka punya waktu luang sehingga waktu luang yang dimiliki bisa dimanfaatkan untuk menyelesaikan pekerjaan yang lain sesuai dengan bidangnya masing-massing; 4) Kinerja LPD Ditinjau dari Perspektif Pertumbuhan dan Pembelajaran yaitu penilaian kinerja perspektif pertumbuhan dan pembelajaran dinilai dari kepuasan karyawan. Kepuasan karyawan ini dicari dengan menyebarkan kuisioner. Hasil pengolahan kuesioner terdiri dari tujuh dimensi kepuasan karyawan yang meliputi: (1) tingkat pendidikan, (2) pengembangan karir, (3) sistem remunerasi atau penggajian, (4) fleksibilitas organisasi, (5) tingkat ketersediaan informasi, (6) tingkat kepuasan kerja, dan (7) tingkat produktivitas karyawan, maka diperoleh Indeks Kepuasan Karyawan sebesar 2.847, sehingga karyawan LPD secara 
keseluruhan dapat dikategorikan cukup puas karena berada pada interval 2.186 2.858. Jika dilihat dari pengukuran ini perusahaan telah mencapai kinerja yang diharapkan. Walaupun memenuhi target kinerja yang diharapkan, tetapi indeks ini masih dapat ditingkatkan lagi pada tahun yang akan datang dengan lebih memperhatikan aspek-aspek yang menjadi perhatian seperti aspek sistem remunerasi atau penggajian, tingkat ketersediaan informasi, dan tingkat kepuasan kerja.

\section{SIMPULAN}

Penilaian kinerja LPD secara keseluruhan yang dinilai dengan metode balanced scorecard berada pada kategori cukup baik, karena diperoleh skor sebesar 2089,13 dan skor ini berada pada interval 1359 - $2716 . \quad K o n d i s i$ ini mengimplikasikan bahwa kinerja LPD masih perlu ditingkatkan agar berada pada kategori sangat baik dengan meningkatkan kinerja LPD dari perspektif keuangan, perspektif pelanggan, serta perspektif pertumbuhan dan pembelajaran

\section{DAFTAR PUSTAKA}

Indra Bastian. 2001. Akuntansi Sektor Publik di Indonesia. Yogyakarta: Pusat Pengembangan Akuntansi FE UGM.

Mulyadi. 2001. Balance Scorecard (Alat manajemen kontemporer untuk melipat ganda kinerja keuangan perusahaan). Jakarta: Penerbit Salemba empat.

Nurjaya, dkk. 2011. Landasan Teoretik Pengaturan LPD. Denpasar: Universitas Udayana.

Suartana, Wayan. 2009. Arsitektur Pengelolaan Risiko Pada Lembaga Perkreditan Desa (LPD). Denpasar: Udayana University Press.

Yuwono, Sony. 2002. Petunjuk Praktis Penyusunan Balanced Scorecard Menuju Organisasi yang Berfokus Pada Strategi. Jakarta: PT Gramedia Pustaka Utama. 